\title{
В. В. СМАЧИЛО
}

\section{НОРМАТИВНО-ПРАВОВЕ ЗАБЕЗПЕЧЕННЯ ДІЯЛЬНОСТІ У СФЕРІ ТРАНСПОРТУ}

Економічна категорія «підприємство транспорту» є загальновживаним в економічному науковому та практичному обігу. Але, в той же час, іï розуміння в правовому полі, яке визначає основи господарської діяльності в сфері транспорту, не є досить чітким. Вказане породжує проблему ідентифікації та віднесення до тієї чи іншої категорії суб'єктів господарювання транспортної галузі. Нормативно-правове забезпечення діяльності транспорту України базується на сукупності загальних законів та кодексів, які регулюють господарську діяльність будь-яких сфер національної економіки країни, а також на спеціальних нормативно-правових актах, які враховують специфіку транспортної сфери. Незважаючи на широке правове поле забезпечення діяльності транспорту, сучасні трансформації та виклики, що стоять перед галуззю, вимагають вирішення певних неузгодженостей задля коректного сприйняття понятійно-категоріального апарату, що формується в правовому полі, та його розвитку у відповідності з потребами часу. Метою дослідження є ідентифікація суб'єктів в сфері транспорту на основ законодавчо-правового підходу. Рекомендовано ввести в нормативно-правове поле визначення транспортного підприємства (підприємства транспорту), яке б корелювало з його дефініцією в Господарському Кодексі України. Пропонуємо розкрити термін «транспортне підприємство» як самостійний суб'єкт господарювання, створений компетентним органом державної влади або органом місцевого самоврядування, або іншими суб'єктами для задоволення суспільних та особистих потреб шляхом систематичного здійснення господарської діяльності в сфері транспорту, відповідно до Закону України «Про транспорт», в порядку, передбаченому Господарським Кодексом та іншими законами України. Чітке окреслення понятійно-категоріального апарату відносно сутності підприємств транспорту в законодавчому полі та його поєднання із класифікацією видів економічної діяльності дозволить в майбутньому коректно формувати сукупність для аналітичної вибірки та здійснювати подальшу класифікацію.

Ключові слова: підприємство, транспорт, транспортні підприємства, вид економічної діяльності, види транспорту, транспортна система.

\section{В. В. СМАЧИЛО \\ НОРМАТИВНО-ПРАВОВОЕ ОБЕСПЕЧЕНИЕ ДЕЯТЕЛЬНОСТИ В СФЕРЕ ТРАНСПОРТА}

Экономическая категория «предприятие транспорта» является общеупотребительной в экономическом научном и практическом обращени и. Но, в то же время, ее понимание в правовом поле, которое определяет основы хозяйственной деятельности в сфере транспорта, не является достаточно четким. Указанное порождает проблему идентификации и отнесения к той или иной категории субъектов хозяйствования транспортной отрасли. Нормативно-правовое обеспечение деятельности транспорта Украины базируется на совокупности общих законов и кодексов, регулирующих хозяйственную деятельность любых сфер национальной экономики страны, а также на специальных нормативноправовых актах, которые учитывают специфику транспортной сферы. Несмотря на широкое правовое поле обеспечения деятельности транспорта, современные трансформации и вызовы, стоящие перед отраслью, требуют решения определенных неточностей для корректн ого восприятия понятийно-категориального аппарата, который формируется в правовом поле, и его развития в соответствии с потребностями времени. Целью исследования является идентификация субъектов в сфере транспорта на основе законодательно-правового подхода. Рекомендуется ввести в нормативно-правовое поле определения транспортного предприятия (предприятия транспорта), которое бы коррелировало с его дефиницией в Хозяйственном кодексе Украины. Предлагаем раскрыть термин «транспортное предприятие» как самостоятельный субъект хозяйствования, созданный компетентным органом государственной власти или органом местного самоуправл ения, или другими субъектами для удовлетворения общественных и личных потребностей путем систематического осуществления хозяйственной деятельности в сфере транспорта, в соответствии с Законом Украины «О транспорте», в порядке, предусмотренном Хозяйственным Кодексом и другими законами Украины. Четкое определение понятийно-категориального аппарата относительно сущности предприятий транспорта в законодательном поле и его сочетание с классификацией видов экономической деятельности позволит в будущем корректно формировать совокупность для аналитической выборки и осуществлять дальнейшую классификацию.

Ключевые слова: предприятие, транспорт, транспортные предприятия, вид экономической деятельности, виды транспорта, транспортная система.

\section{V. SMACHYLO}

\section{NORMATIVE-LEGAL FRAMEWORK OF TRANSPORT}

The economic category «transport enterprise» is commonly used in economic scientific and practical circulation. However, at the same time, its understanding in the legal field, which defines the basis of economic activity in the field of transport, is not very clear. The above-mentioned raises the problem of identification and attribution to one or another category of business entities in the transport sector. Regulatory support of the transport of Ukraine is based on a set of general laws and codes that regulate the economic activity of any areas of the national economy of the country, as well as on special regulatory acts that take into account the specifics of the transport sphere. Despite the broad legal framework for ensuring transport activity, modern transformations and challenges facing the industry require the resolution of certain inconsistencies in order to properly perceive the conceptcategorical apparatus that is formed in the legal field and its development in accordance with the needs of the time. The purpose of the study is to identify entities in the field of transport on the basis of legislative and legal approach. It is recommended to introduce in the legal and regulatory framework the definition of a transport undertaking (transport company), which would correlate with its definition in the Commercial Code of Ukraine. We propose to disclose the term «transport enterprise» as an independent economic entity created by the competent state authority or local self-government body or other entities to meet social and personal needs through the systematic implementation of economic activities in the field of transport in accordance with the Law of Ukraine «On Transport» in accordance with the procedure provided by the Commercial Code and other laws of Ukraine. A clear definition of the conceptual-categorical apparatus relative to the essence of transport enterprises in the legislative field and its combination with the classification of economic activities will allow in the future to correctly form the population for the analytical sample and carry out further classification.

Keywords: enterprise, transport, transport enterprises, type of economic activity, types of transport, transport system.

Вступ. Економічна категорія «підприємство транспорту» $\epsilon$ загальновживаним в економічномунауковому та практичному обігу. Але, в той же час, іiі розуміння в правовому полі, яке визначає основи господарської діяльності в сфері транспорту, не є досить чітким.
Вказане породжує проблему ідентифікації та віднесення до тієї чи іншої категорії суб'єктів господарювання транспортної галузі.

Аналіз основних досягнень i літератури. Нормативно-правове забезпечення діяльності 
транспорту України базується на сукупності загальних законів та кодексів, які регулюють господарську діяльність будь-яких сфер національної економіки країни: Господарський Кодекс України [1], Податковий Кодекс України, Цивільний Кодекс України, Кодексу законів про працю в Україні, Закон України «Про оплату праці», Закон України «Про колективні договори та угоди», тощо. Спеціалізована правова база представлена Законом України «Про транспорт» [2], Законом «України «Про залізничний транспорт» [3], Законом України «Про автомобільний транспорт» [4] та іншими. Саме вказані документи стали основою вивчення нормативно-правового забезпечення діяльності суб'єктів господарювання транспортної галузі. Окрім того, досліджувалися публікації вітчизняних вчених [5,6], де представлено аналіз існуючих законодавчих положень та неузгоджень в сфері економіки транспорту.

Постановка задачі (проблеми). Незважаючи на широке правове поле забезпечення діяльності транспорту, сучасні трансформації та виклики, що стоять перед галуззю, вимагають вирішення певних неузгодженостей задля коректного сприйняття понятійно-категоріального апарату, що формується в правовому полі, та його розвитку у відповідності 3 потребами часу.

Метою статті є ідентифікація суб'єктів в сфері транспорту на основі законодавчо-правового підходу.

Результати. Транспорт визначається однією 3 найважливіших галузей суспільного виробництва, призначенням якої є задоволення потреби населення та суспільного виробництва в перевезеннях [2].

Транспортна галузь, займає важливе місце в економіці України, так, виходячи із структури валової доданої вартості за I кв. 2018p., їі частка становила $8,2 \%$ (для порівняння: будівництво - лише 2,2\%, сільське господарство - 4,0\%, хоча нижче, аніж в промисловості - 27,7\% та торгівлі - 17,5\%) [7]. Але важливість транспортного комплексу, на думку автора, визначається не лише його прямим позитивним економічним впливом на ВВП, але й опосередкованим, адже розвинена транспортна інфраструктура спричиняє мультиплікативний ефект у вигляді підвищення доступності інвесторів, туристів та власних громадян до будь-якого місця України. А це, в свою чергу, обумовлює створення логістичних хабів, нових робочих місця, пожвавлює виробництво та торгівлю, туризм, тим самим підвищуючи загальне ВВП та ВРП. Державне управління в галузі транспорту здійснюють центральний орган виконавчої влади, що забезпечує формування та реалізує державну політику у сфері транспорту, дорожнього господарства, туризму та інфраструктури (Міністерство інфраструктури України), місцеві Ради народних депутатів та інші спеціально уповноважені на те органи відповідно до їх компетенції [2]. Склад єдиної транспортної системи визначається Законом України «Про транспорт» (рис. 1). Окрім нього, діяльність в сфері транспорту регулює цілий ряд нормативно-правових актів (Закони України «Про міський електротранспорт» [8], «Про трубопровідний транспорт» [9], «Про автомобільний транспорт» [4], «Про залізничний транспорт»[3], Повітряний та Водний Кодекси $[10,11]$ та інші), а також передбачено ліцензування цього виду діяльності. Так, Ліцензійні умови провадження господарської діяльності 3 перевезення пасажирів, небезпечних вантажів та небезпечних відходів автомобільним транспортом, міжнародних перевезень пасажирів та вантажів автомобільним транспортом, затверджено постановою Кабінету Міністрів України від 02.12.2015 № 1001 [13]; Порядок здійснення державного контролю на автомобільному транспорті, затверджено

\begin{tabular}{|c|c|c|c|}
\hline & \multicolumn{2}{|c|}{ Єаина транспортна снстема Украйни } & \\
\hline 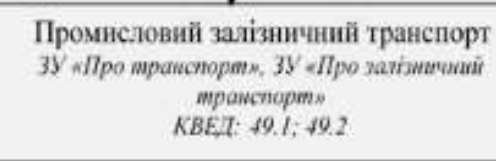 & \multicolumn{2}{|c|}{ 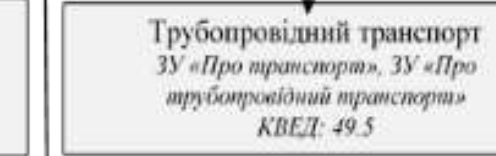 } & 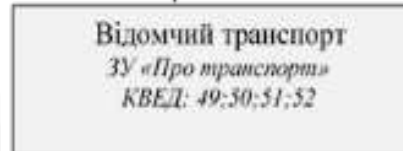 \\
\hline \multicolumn{3}{|c|}{ 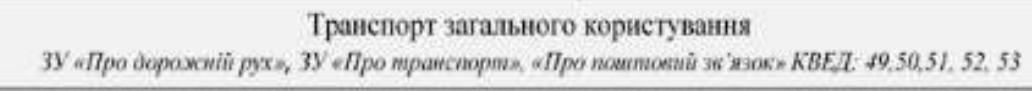 } & $\begin{array}{c}\text { ШІляхи сполучсння загального } \\
\text { користування }\end{array}$ \\
\hline \multicolumn{2}{|c|}{ 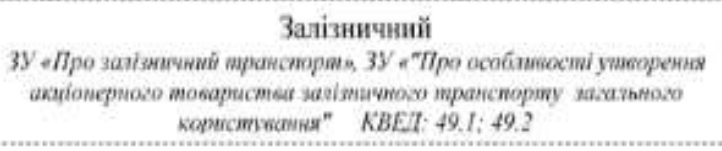 } & \multicolumn{2}{|c|}{ 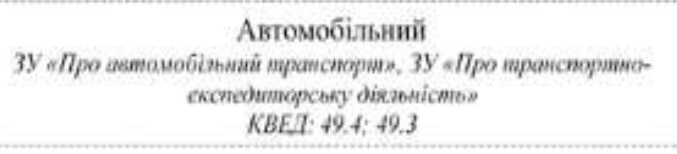 } \\
\hline 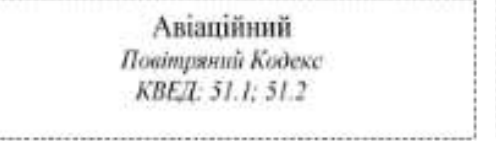 & \multicolumn{2}{|c|}{ 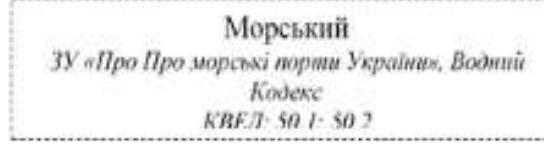 } & 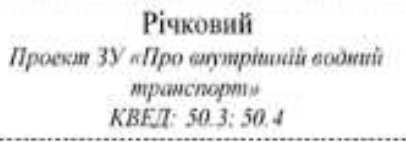 \\
\hline \multicolumn{4}{|c|}{ 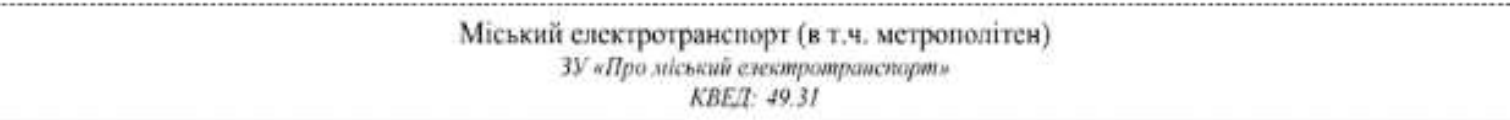 } \\
\hline
\end{tabular}

Рис. 1. Склад Сдиної транспортної системи України (побудовано на основі [2-4, 2-12, 15-19] 
постановою Кабінету Міністрів України від 08.11.2006 № 1567 [14].

Основою господарської діяльності підприємств транспорту визначено перевезення пасажирів, вантажів, багажу та пошти, надання інших транспортних послуг, експлуатація і ремонт шляхів сполучення здійснюються залізницями, пароплавствами, суб'єктами господарювання у морських портах, автомобільними, авіаційними, дорожніми підприємствами та організаціями, якщо це передбачено їх статутами [2].

В той же час, безпосередньо надання транспортних послуг, як економічної сутнісної характеристики транспортних підприємств, відбувається в межах КВЕД 2010 «Транспорт, складське господарство, поштова та кур'єрська діяльність» секція Н та включає [19]: забезпечення пасажирських і вантажних перевезень (за розкладом або ні), залізничним, трубопровідним, автомобільним, водним або повітряним транспортом, а також допоміжну діяльність, таку як діяльність терміналів і автостоянок, вантажно-розвантажувальні роботи, зберігання тощо. Ця секція також включає надання в оренду транспортних засобів разом із водієм або екіпажем. Також до секції віднесена поштова та кур'єрська діяльність. В межах цієї секції КВЕД здійснюється розподіл за розділами [19]: 49 - наземний і трубопровідний транспорт; 50 - водний транспорт; 51 - авіаційний транспорт; 52 - складське господарство та допоміжна діяльність у сфері транспорту; 53 - поштова та кур'єрська діяльність. В межах кожного розділу виділяються окремі підвиди. На рис.1 відображено основну законодавчу базу діяльності транспорту за рівнями транспортної системи та в розрізі видів транспорту із врахуванням шифрів основної економічної діяльності згідно КВЕД:2010.

Розкриємо визначення кожного виду транспорту загального користування, керуючись нормативноправовою базою України (табл. 1).

Можемо відмітити, що діяльність багатьох видів транспорту загального користування регулюється окремими законодавчими актами. В той же час, не всі існуючі визначення видів транспорту в різних документах корелюють між собою, що викликає певну неусталеність нормативно-правової бази сфери транспорту та її понятійно-категоріального апарату. Якщо в ЗУ «Про транспорт», до того чи іншого виду транспорту віднесено не лише підприємства, що забезпечують транспортні послуги, а й обслуговуючі, то в спеціалізованих законах - передбачено лише перевезення.

Крім того, складові єдиної транспортної системи, що не входять до транспорту загального користування, не знайшли свого визначення в ЗУ «Про транспорт» [2], але представлені в інших законодавчих актах (діяльність трубопровідного транспорту регулюється окремим законом «Про трубопровідний транспорт» [9]). А визначення промислового залізничного транспорту наведене в Законі України «Про залізничний транспорт», та трактується як транспортно-технологічний комплекс, який забезпечує системне переміщення вантажів у процесі виробництва (між виробництвами, виробничими циклами, окремими операціями або підприємст- вами в цілому) та взаємодію із залізничним транспортом загального користування i не належить до нього [3].

В Законі [2] відсутні визначення таких складових єдиної транспортної системи як «відомчий транспорт» - лише вказано, що до його складу входять транспортні засоби підприємств, установ та організацій (відповідно, діяльність відомчого транспорту буде здійснюватися в межах всієї секції Н за КВЕД 2010) та «шляхи сполучення загального користування».

Також слід відмітити наявність Проекту Закону України «Про внутрішній водний транспорт» [21], де визначено внутрішній водний транспорт як «вид транспорту, до якого належать судна, суб'єкти господарювання, що здійснюють та забезпечують перевезення переважно річковими водними шляхами вантажів, пасажирів, багажу і пошти, надають інші послуги з використанням суден внутрішнього плавання, забезпечують судноплавство по річковим водним шляхам, утримають об'єкти інфраструктури внутрішніх водних шляхів, здійснюють навігаційно-гідрографічне забезпечення судноплавства».

Зауважимо, що словосполучення водний транспорт не означене в ЗУ «Про транспорт», що знову ж таки викликає певну неусталеність у дефініціях. У той же час, таке трактування відповідає КВЕД 2010 (рис. 1). Отже, законодавча дефініція видів транспорту $\epsilon$ неусталеною та неоднозначною в різних законодавчих актах, що потребує ії упорядкування.

В ЗУ «Про транспорт» вказано за видами транспорту, що це підприємства, які не тільки надають транспортні послуги, а й виконують інші види діяльності для забезпечення транспортування (навчання, будівництво, ремонт, тощо).

Здійснимо співвіднесення складових транспортної системи та видів економічної діяльності більш детально, розкриваючи окремі розділи (рис. 2) поклавши в основу економічну сутність транспортних підприємств - ті, які надають транспортні послуги.

Відмічаємо, що в основу поділу за видами економічної діяльності частково покладено види транспорту та типи перевезень. Слід наголосити на чіткій відповідності видів економічної діяльності та класифікації діяльності за авіаційним транспортом згідно [2]; морський та річковий види транспорту представлені окремим розділом - водний транспорт, де виділені морський та річковий види транспорту за типами перевезень - пасажирські та вантажні (аналогічно й для авіаційного). Інші види транспорту загального користування, промисловий залізничний та трубопровідний транспорт узагальнено в розділі 49, де відсутній чіткий поділ за видами транспорту та типами перевезень.

Можемо відмітити, що відсутній чіткий код для такого виду діяльності як «пасажирські перевезення автомобільним транспортом», в той час, як виділяється «вантажний транспорт». Саме група 49.3 розподіляється на пасажирський наземний транспорт міського та приміського сполучення, надання послуг таксі та інший пасажирський наземний транспорт, н.в.і.у. [19]. 
Таблиця 1 - Ідентифікація видів транспорту в правовому полі України (узагальнено автором)

\begin{tabular}{|c|c|c|}
\hline Вид транспорту & Закон України «Про транспорт» [2] & Інші законодавчі акти \\
\hline $\begin{array}{l}\text { Залізничий } \\
\text { транспорт }\end{array}$ & $\begin{array}{l}\text { підприємства, що здійснюють перевезення } \\
\text { пасажирів, вантажів, багажу, пошти, рухомий склад } \\
\text { залізничного транспорту, залізничні шляхи } \\
\text { сполучення, а також промислові, будівельні, } \\
\text { торговельні та постачальницькі підприємства, } \\
\text { навчальні заклади, технічні школи, дитячі дошкільні } \\
\text { заклади, заклади охорони здоров'я, фізичної } \\
\text { культури та спорту, культури, науково-дослідні, } \\
\text { проектно-конструкторські організації, підприємства } \\
\text { промислового залізничного транспорту та інші } \\
\text { підприємства, установи та організації незалежно від } \\
\text { форм власності, що забезпечують його діяльність і } \\
\text { розвиток [2]. }\end{array}$ & $\begin{array}{l}\text { виробничо-технологічний } \\
\text { комплекс підприємств } \\
\text { залізничного транспорту, } \\
\text { призначений для забезпечення } \\
\text { потреб суспільного виробництва і } \\
\text { населення країни в перевезеннях у } \\
\text { внутрішньому і міжнародному } \\
\text { сполученнях та надання інших } \\
\text { транспортних послуг усім } \\
\text { споживачам без обмежень за } \\
\text { ознаками форми власності та видів } \\
\text { діяльності тощо [3]. }\end{array}$ \\
\hline $\begin{array}{l}\text { Морський } \\
\text { транспорт }\end{array}$ & \multicolumn{2}{|c|}{$\begin{array}{l}\text { підприємства, що здійснюють перевезення пасажирів, вантажів, багажу, пошти, судна, } \\
\text { судноремонтні заводи, морські шляхи сполучення, а також підприємства зв'язку, } \\
\text { промислові, торговельні, будівельні і постачальницькі підприємства, навчальні заклади, } \\
\text { заклади охорони здоров'я, фізичної культури, науково-дослідні, проектно-конструкторські } \\
\text { організації та інші підприємства, установи та організації незалежно від форм власності, що } \\
\text { забезпечують роботу морського транспорту [2]. }\end{array}$} \\
\hline $\begin{array}{l}\text { Річковий } \\
\text { транспорт }\end{array}$ & \multicolumn{2}{|c|}{$\begin{array}{l}\text { підприємства, що здійснюють перевезення пасажирів, вантажів, багажу, пошти, порти і } \\
\text { пристані, судна, суднобудівно-судноремонтні заводи, ремонтно-експлуатаційні бази, } \\
\text { підприємства шляхового господарства, а також підприємства зв'язку, промислові, } \\
\text { торговельні, будівельні та постачальницькі підприємства, навчальні заклади, заклади } \\
\text { охорони здоров'я, фізичної культури та спорту, культури, проектно-конструкторські } \\
\text { організації та інші підприємства, установи і організації незалежно від форм власності, що } \\
\text { забезпечують роботу річкового транспорту [2]. }\end{array}$} \\
\hline $\begin{array}{c}\text { Автомобільний } \\
\text { транспорт }\end{array}$ & $\begin{array}{l}\text { підприємства, що здійснюють перевезення } \\
\text { пасажирів, вантажів, багажу, пошти, авторемонтні і } \\
\text { шиноремонтні підприємства, рухомий склад } \\
\text { автомобільного транспорту, транспортно- } \\
\text { експедиційні підприємства, а також автовокзали і } \\
\text { автостанції, навчальні заклади, ремонтно-будівельні } \\
\text { організації та соціально-побутові заклади, інші } \\
\text { підприємства, установи та організації незалежно від } \\
\text { форм власності, що забезпечують роботу } \\
\text { автомобільного транспорту [2]. }\end{array}$ & $\begin{array}{l}\text { галузь транспорту, яка забезпечує } \\
\text { задоволення потреб населення та } \\
\text { суспільного виробництва у } \\
\text { перевезеннях пасажирів та } \\
\text { вантажів автомобільними } \\
\text { транспортними засобами [4]. }\end{array}$ \\
\hline $\begin{array}{l}\text { Авіаційний } \\
\text { транспорт }\end{array}$ & \multicolumn{2}{|c|}{$\begin{array}{l}\text { підприємства, що здійснюють перевезення пасажирів, вантажів, багажу, пошти, } \\
\text { аерофотозйомки, сільськогосподарські роботи, а також аеропорти, аеродроми, аероклуби, } \\
\text { транспортні засоби, системи управління повітряним рухом, навчальні заклади, ремонтні } \\
\text { заводи цивільної авіації та інші підприємства, установи та організації незалежно від форм } \\
\text { власності, що забезпечують роботу авіаційного транспорту [2]. }\end{array}$} \\
\hline $\begin{array}{c}\text { Міський } \\
\text { електротранспорт }\end{array}$ & $\begin{array}{l}\text { підприємства, що здійснюють перевезення } \\
\text { пасажирів, вантажів, багажу, пошти, рухомий склад, } \\
\text { трамвайні і тролейбусні лінії, ремонтно- } \\
\text { експлуатаційні депо, службові приміщення, } \\
\text { фунікулери, канатні дороги, ескалатори, заводи по } \\
\text { ремонту рухомого складу і виготовленню запасних } \\
\text { частин, споруди енергетичного господарства та } \\
\text { зв'язку, промислові, ремонтно-будівельні, } \\
\text { торговельні та постачальницькі організації, } \\
\text { навчальні заклади, науково-дослідні та проектно- } \\
\text { конструкторські установи, заклади охорони здоров'я, } \\
\text { відпочинку, фізичної культури і спорту та інші } \\
\text { культурно-побутові заклади і підприємства, } \\
\text { установи та організації незалежно від форм } \\
\text { власності, що забезпечують роботу міського } \\
\text { електротранспорту [2]. }\end{array}$ & $\begin{array}{l}\text { складова частина єдиної } \\
\text { транспортної системи, призначена } \\
\text { для перевезення громадян } \\
\text { трамваями тролейбусами, поїздами } \\
\text { метрополітену на маршрутах } \\
\text { (лініях) відповідно до вимог } \\
\text { життєзабезпечення населених } \\
\text { пунктів [8]. }\end{array}$ \\
\hline
\end{tabular}

Отже, діяльність в сфері пасажирських перевезень автомобільним транспортом буде відповідати КВЕД 49.3 (49.31 та 49.39).

Господарська діяльність в цій сфері, як і в будьякій іншій, відбувається на основі українського законодавства, відповідно до якого пї можуть здійснювати суб'єкти господарювання - юридичні та фізичні особи, зареєстровані у встановленому порядку у відповідності із видами економічної діяльності [1]. 


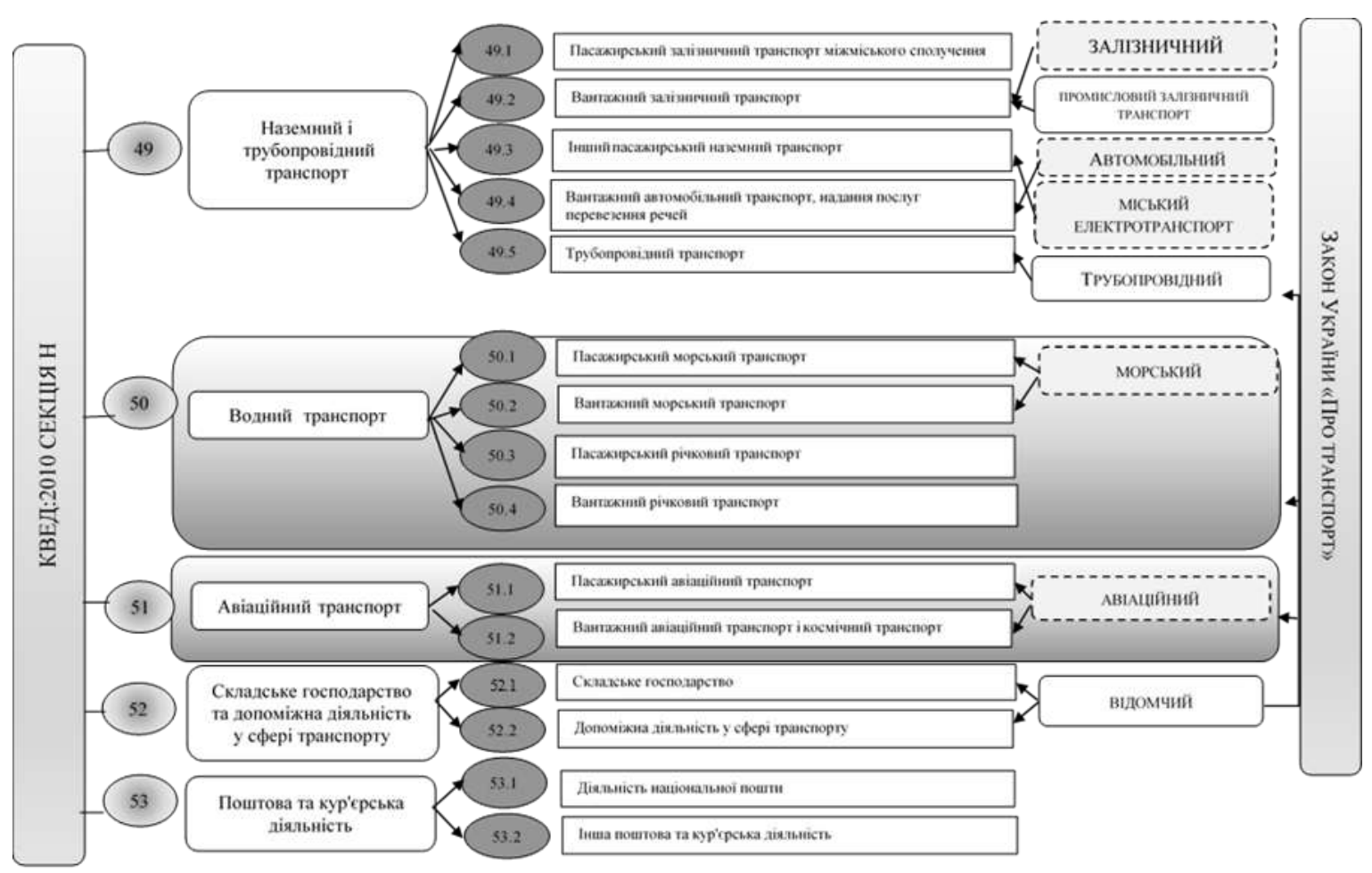

Рис. 2. Узгодження видів транспорту та видів економічної діяльності (побудовано автором на основі $[2,19])$

Господарський кодекс України, як одного із суб'єктів господарювання визначає, юридичну особу підприємство.

Аналіз інших законодавчих актів в сфері транспорту демонструє певні неузгодженості як щодо суб'єктів господарювання, так і щодо розуміння підприємства транспорту того чи іншого виду. Порівняльна таблиця 2, презентує декілька понять, які характеризують суб'єктів господарювання в сфері того чи іншого виду транспорту. Серед них слід відмітити терміни: «суб'єкт господарювання», «перевізник», «підприємство (а)».

При цьому перевізник (за видами транспорту) визначається як суб'єкт господарювання (може бути як фізичною, так і юридичною особою), яка надає послуги 3 перевезення, транспортування. Підприємство ж $є$ більш вужчим поняттям, аніж суб'єкт господарювання (перевізник), бо передбачає утворення юридичної особи. В той же час, знову слід відмітити неусталеність у визначеннях в законодавчому полі щодо розуміння терміну «перевізник» - фізична і юридична чи лише юридична. Така неусталеність обумовлена певними специфічними рисами в сфері діяльності транспорту: міський електротранспорт $є$ монополізованим та не передбачає діяльність приватних структур, в той час як автомобільний транспорт $є$ найменш монополізованим та характеризується високим рівнем конкуренції як серед юридичних, так i серед фізичних осіб, що провадить господарську діяльність в галузі перевезень пасажирів та вантажів.

Зауважимо, термін «перевізник» передбачає надання транспортних послуг, перевезення вантажів чи пасажирів тим чи іншим видом транспорту, що не узгоджується 3 переліком підприємств за ЗУ «Про транспорт», де передбачені не лише перевезення, а й інші підприємства (обслуговуючі, ремонтні, тощо).

Тому вищевказані терміни не $\epsilon$ узгодженими між собою в правовому полі транспорту України. На наш погляд, найбільш широкою характеристикою є суб'єкт господарювання, який може бути як фізичною, так і юридичною особою та здійснювати будь-які види діяльності згідно КВЕД; підприємство може бути лише юридичною особою; перевізник же обмежений лише сферою надання послуг з транспортування. Крім того, в науковому та повсякденному обігу вживаються терміни «транспортне підприємство» та «підприємство транспорту», які пропонуємо вживати як синоніми. Співвідношення вказаних термінів наведено на рис. 3.

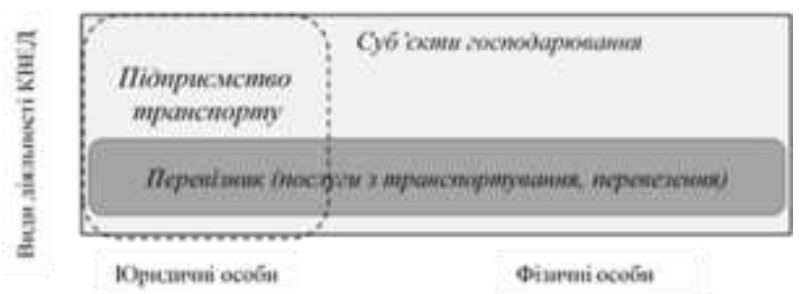

Рис. 3. Співвідношення термінів стосовно суб'єктів, що провадять діяльність в сфері транспорту (розроблено автором)

Таким чином, законодавчі акти України не містять визначення поняття «транспортне підприємство»; зустрічається лише його індентифікація за видами транспорту (автотрнаспортне підприємства, підприємства залізничного транспорту).

Виходячи 3 вищенаведеного, доцільно ввести в нормативно-правове поле визначення транспортного 
Таблиця 2 - Узагальнення визначень суб’єктів, які здійснюють в діяльність в сфері транспорту за законодавчо-правовим підходом (узагальнено автором)

\begin{tabular}{|c|c|}
\hline Визначення & Джерело \\
\hline \multicolumn{2}{|l|}{ Суб’єкт } \\
\hline $\begin{array}{l}\text { Суб'єкт авіаційної діяльності - фізичні та юридичні особи незалежно від форми власності, відомчої } \\
\text { підпорядкованості, які провадять діяльність у галузі цивільної авіації; }\end{array}$ & [10] \\
\hline \multicolumn{2}{|l|}{ Перевізник } \\
\hline $\begin{array}{l}\text { Автомобільний перевізник - фізична або юридична особа, яка здійснює на комерційній основі чи за } \\
\text { власний кошт перевезення пасажирів чи (та) вантажів транспортними засобами; }\end{array}$ & \multirow[t]{3}{*}{ [4] } \\
\hline $\begin{array}{l}\text { Автомобільний самозайнятий перевізник - це фізична особа - суб'єкт господарювання, яка здійснює } \\
\text { на комерційній основі чи за власний кошт перевезення пасажирів на таксі без застосування праці } \\
\text { найманих водіїв; }\end{array}$ & \\
\hline $\begin{array}{l}\text { Автомобільним перевізником та автомобільним самозайнятим перевізником, які здійснюють } \\
\text { перевезення пасажирів на договірних умовах, є суб'єкти господарювання, які відповідно до } \\
\text { законодавства та одержаної ліцензії надають послуги за договором перевезення пасажирів } \\
\text { транспортним засобом, що використовується ними на законних підставах. }\end{array}$ & \\
\hline $\begin{array}{l}\text { Перевізник - юридична або фізична особа, яка взяла на себе зобов'язання і відповідальність за } \\
\text { договором перевезення вантажу за доставку до місця призначення довіреного ӥй вантажу, } \\
\text { перевезення вантажів та їх видачу (передачу) вантажоодержувачу або іншій особі, зазначеній у } \\
\text { документі, що регулює відносини між експедитором та перевізником; }\end{array}$ & [15] \\
\hline $\begin{array}{l}\text { Перевізник - суб'єкт господарювання, який здійснює перевезення вантажів, пасажирів та їх майна, } \\
\text { багажу, пошти внутрішнім водним транспортом; }\end{array}$ & [20] \\
\hline $\begin{array}{l}\text { Перевізник - юридична особа, яка в установленому законодавством порядку надає транспортні } \\
\text { послуги, здійснюючи експлуатацію та утримання об'єктів міського електричного транспорту; }\end{array}$ & [8] \\
\hline \multicolumn{2}{|l|}{ Підприємство } \\
\hline $\begin{array}{l}\text { Підприємства залізничного транспорту - суб'єкти господарювання, які провадять діяльність у сфері } \\
\text { залізничного транспорту }\end{array}$ & [3] \\
\hline $\begin{array}{l}\text { Автотранспортне підприємство надає послуги з перевезення пасажирів міським та приміським } \\
\text { автомобільним транспортом, у тому числі й пільгових категорій пасажирів. }\end{array}$ & [21] \\
\hline $\begin{array}{l}\text { Підприємство з обслуговування річкових водних шляхів - юридична особа державної форми } \\
\text { власності, утворена з метою обслуговування річкових водних шляхів, утримання та використання } \\
\text { об’єктів інфраструктури внутрішнього водного транспорту державної форми власності, забезпечення } \\
\text { функціонування річкової інформаційної служби, виконання інших покладених на неї відповідно до } \\
\text { закону завдань. }\end{array}$ & [20] \\
\hline
\end{tabular}

підприємства (підприємства транспорту), яке б корелювало $з$ його дефініцією в Господарському Кодексі України. Пропонуємо розкрити термін «транспортне підприємство» як самостійний суб'єкт господарювання, створений компетентним органом ржавної влади або органом місцевого самоврядування, або іншими суб'єктами для задоволення суспільних та особистих потреб шляхом систематичного здійснення господарської діяльності в сфері транспорту, відповідно до Закону України «Про транспорт», в порядку, передбаченому Господарським Кодексом та іншими законами України.

Результати та подальші напрямки досліджень.

Чітке окреслення понятійно-категоріального апарату відносно сутності підприємств транспорту в законодавчому полі та його поєднання із класифікацією видів економічної діяльності дозволить в майбутньому коректно формувати сукупність для аналітичної вибірки та здійснювати подальшу класифікацію.

\section{Список літератури}

1. Господарський кодекс Украйни. https://zakon.rada.gov.ua/laws/show/436-15 (дата

URL: 20.04.2019).

2. Закон України «Про транспорт». URL: https://zakon.rada.gov.ua/laws/show/232/94-\%D0\%B2\%D1\%80 (дата звернення 20.04.2019).
3. Закон України «Про залізничний транспорт». URL: https://zakon.rada.gov.ua/laws/show/273/96-\%D0\%B2\%D1\%80 (дата звернення 20.04.2019).

4. Закон Украйни «Про автомобільний транспорт». URL: https://zakon1.rada.gov.ua/laws/show/2344-14 (дата звернення 20.04.2019).

5. Рябова К. О. Особливості правового статусу підприсмств транспорту. Юридичний вісник. Повітряне і космічне право. 2018. № 1. С. 144-149.

6. Скоромний Д.А. Система транспорту та система перевезень за законодавством Украӥни URL:http://apir.org.ua/wpcontent/uploads/2014/11/skoromnyy_ua.pdf (дата звернення 20.04.2019).

7. Офіиійний сайт Державної служби статистики України. URL: http://www.ukrstat.gov.ua/ (дата звернення 20.04.2019).

8. Закон Украӥни «Про міський електричний транспорт». URL: https://zakon.rada.gov.ua/laws/show/1914-15 (дата звернення 20.04.2019).

9. Закон України «Про трубопровідний транспорт». URL: https://zakon.rada.gov.ua/laws/show/192/96-\%D0\%B2\%D1\%80 (дата звернення 20.04.2019).

10. Повітряний кодекс Украӥни. URL: https://zakon.rada.gov.ua/laws/show/3393-17 (дата звернення 20.04.2019).

11. Водний кодекс Украӥни. (1/zakon.rada.gov.ua/laws/show/213/95-\%D0\%B2\%D1\%80 (дата звернення 20.04.2019)/

12. Закон Украӥни «Про морські порти Украӥни». URL: https://zakon.rada.gov.ua/laws/show/4709-17 (дата звернення 20.04.2019)

13. Лічензійні умови провадження господарської діяльності 3 перевезення пасажирів, небезпечних вантажів та небезпечних відходів автомобільним транспортом, міжнародних перевезень 
пасажсирів та вантажів автомобільним транспортом. URL: https://zakon.rada.gov.ua/laws/show/1001-2015-\%D0\%BF (дата звернення 20.04.2019).

14. Порядок здійснення державного контролю на автомобільному транспорт. URL: https://zakon.rada.gov.ua/laws/show/1567-2006$\% \mathrm{D} 0 \% \mathrm{BF}$ (дата звернення 20.04.2019).

15. Закон Украӥни «Про транспортно-експедиторську діяльність». URL: https://zakon.rada.gov.ua/laws/show/1955-15 (дата звернення 20.04.2019).

16. Закон України «Про дорожній рух». URL: https://zakon.rada.gov.ua/laws/show/3353-12 (дата звернення 20.04.2019).

17. Закон Украйни «Про поштовий зв'язок». URL: https://zakon.rada.gov.ua/laws/show/2759-14 (дата звернення 20.04.2019).

18. Закон Украӥни «Про особливості утворення акціонерного товариства залізничного транспорту загального користування». URL: https://zakon.rada.gov.ua/laws/show/4442-17 (дата звернення 20.04.2019).

19. Класифікатор видів економічної діяльності 2010. URL: ved.ukrstat.gov.ua/KVED2010/kv10 i.html (дата звернення 20.04.2019).

20. Проект Закону Украӥни «Про внутрішній водний транспорт». URL:

http://w1.c1.rada.gov.ua/pls/zweb2/webproc4_1?pf3511=64397 (дата звернення 20.04.2019).

21. Офіиійні відповідi. $U R L$ https://zakon.rada.gov.ua/rada/show/p1180697-03 (дата звернення 20.04.2019)

\section{References (transliterated)}

1. Hospodarskyi kodeks Ukrainy [Economic Code of Ukraine]. URL: https://zakon.rada.gov.ua/laws/show/436-15 (accessed 20.04.2019).

2. Zakon Ukrainy Pro transport [Law of Ukraine On Transport]. URL: https://zakon.rada.gov.ua/laws/show/232/94-\%D0\%B2\%D1\%80 (accessed 20.04.2019).

3. Zakon Ukrainy Pro zaliznychnyi transport [Law of Ukraine on Railway Transport]. URL: https://zakon.rada.gov.ua/laws/show/273/96-\%D0\%B2\%D1\%80 (accessed 20.04.2019).

4. Zakon Ukrainy Pro avtomobilnyi transport [Law of Ukraine on Road Transport]. URL: https://zakon1.rada.gov.ua/laws/show/2344-14 (accessed 20.04.2019).

5. Riabova K. O. Osoblyvosti pravovoho statusu pidpryiemst transportu [Features of the legal status of transport enterprises] Yurydychnyi visnyk. Povitriane i kosmichne pravo. 2018, no. 1, pp 144-149.

6. Skoromnyi D.A. Systema transportu ta systema perevezen za zakonodavstvom Ukrainy [Transport system that system is transported by the legislation of Ukraine]. URL: http://apir.org.ua/wp-content/uploads/2014/11/skoromnyy_ua.pdf (accessed 20.04.2019).
7. Ofitsiinyi sait Derzhavnoi sluzhby statystyky Ukrainy. URL: http://www.ukrstat.gov.ua/ (accessed 20.04.2019).

8. Zakon Ukrainy Pro miskyi elektrychnyi transport [Law of Ukraine on urban electric transport]. Available at: https://zakon.rada.gov.ua/laws/show/1914-15 (accessed 20.04.2019).

9. Zakon Ukrainy Pro truboprovidnyi transport [Law of Ukraine on pipeline transport]. URL: //zakon.rada.gov.ua/laws/show/192/96$\%$ D0\%B2\%D1\%80 (accessed 20.04.2019).

10. Povitrianyi kodeks Ukrainy [Air Code of Ukraine]. URL: https://zakon.rada.gov.ua/laws/show/3393-17 (accessed 20.04.2019).

11. Vodnyi kodeks Ukrainy [Water Code of Ukraine]. URL: https://zakon.rada.gov.ua/laws/show/213/95-\%D0\%B2\%D1\%80 (accessed 20.04.2019).

12. Zakon Ukrainy Pro morski porty Ukrainy [Law of Ukraine on Sea ports of Ukraine]. URL: https://zakon.rada.gov.ua/laws/show/4709. 17 (accessed 20.04.2019).

13. Litsenziini umovy provadzhennia hospodarskoi diialnosti z perevezennia pasazhyriv, nebezpechnykh vantazhiv ta nebezpechnykh vidkhodiv avtomobilnym transportom, mizhnarodnykh perevezen pasazhyriv ta vantazhiv avtomobilnym transportom [Licensing conditions for conducting business activities for the carriage of passengers, dangerous goods and hazardous wastes by road, international transportation of passengers and goods by road] URL: https://zakon.rada.gov.ua/laws/show/1001-2015-\%D0\%BF (accessed 20.04.2019).

14. Poriadok zdiisnennia derzhavnoho kontroliu na avtomobilnomu transport [The order of state control in road transport] URL: https://zakon.rada.gov.ua/laws/show/1567-2006-\%D0\%BF (accessed 20.04.2019).

15. Zakon Ukrainy Pro transportno-ekspedytorsku diialnist [Law of Ukraine On Freight Forwarding Activities]. URL: https://zakon.rada.gov.ua/laws/show/1955-15 (accessed 20.04.2019).

16. Zakon Ukrainy Pro dorozhnii rukh [Law of Ukraine on Road Traffic]. URL: https://zakon.rada.gov.ua/laws/show/3353-12 (accessed 20.04.2019).

17. Zakon Ukrainy Pro poshtovyi zviazok [Law of Ukraine on postal services]. URL: https://zakon.rada.gov.ua/laws/show/2759-14 (accessed 20.04.2019).

18. Zakon Ukrainy Pro osoblyvosti utvorennia aktsionernoho tovarystva zaliznychnoho transportu zahalnoho korystuvannia [Law of Ukraine On peculiarities of railway transport company public]. URL: https://zakon.rada.gov.ua/laws/show/4442-17 (accessed 20.04.2019).

19. Klasyfikator vydiv ekonomichnoi diialnosti 2010. URL: ved.ukrstat.gov.ua/KVED2010/kv10_i.html (accessed 20.04.2019).

20. Proekt Zakonu Ukrainy "Pro vnutrishnii vodnyi transport» [Draft Law of Ukraine On Inland Water Transport]. URL: http://w1.c1.rada.gov.ua/pls/zweb2/webproc4_1?pf3511=64397 (accessed 20.04.2019).

21. Ofitsiini vidpovidi [Official answers] URL: https://zakon.rada.gov.ua/rada/show/p1180697-03 (accessed 20.04.2019).

Відомості про авторів / Сведения об авторах / About the Authors

Смачило Валентина Володимирівна (Смачило Валентина Владимировна, Smachylo Valentyna) -кандидат економічних наук, доцент, Харківський національний університет будівництва та архітектури, професор кафедри економіки, м. Харків, Україна; ORCID: https://orcid.org/0000-0002-6153-1564; e-mail: miroslava.valya@ukr.net 